\title{
The Potentiality of Lysinibacillus sphaericus DM-3 and Bacillus cereus DM-5 in Degrading Dimethoate
}

\author{
Mahmoud S.M. Mohamed ${ }^{(1) \#}$, Ahmed Fahmy A. Youssef ${ }^{(2)}$ and Yara Ahmed \\ Mohamed $^{(3)}$ \\ ${ }^{(1)}$ Department of Botany \& Microbiology; (2)Department of Chemistry, Faculty of \\ Science, Cairo University and (3) Faculty of Biotechnology, October University of \\ Modern Science and Arts, Giza, Egypt.
}

\begin{abstract}
TWO BACTERIAL strains were isolated by soil enrichment technique and identified as Lysinibacillus sphaericus DM-3 and Bacillus cereus DM-5. Biodegradation experiments were performed in carbon free-mineral salt media supplemented with $100 \mathrm{mg} / \mathrm{L}$ of dimethoate. The ability of bacterial strains to degrade the dimethoate was evaluated under various conditions such as $\mathrm{pH}$ range, temperature and different concentrations of dimethoate. The dimethoate residue was determined quantitatively by HPLC method and the degradation byproducts were identified by GC/MS technique. The results revealed that both bacterial strains can utilize dimethoate as a sole carbon source up to a concentration of $500 \mathrm{mg} / \mathrm{L}$. The optimum temperature for both strains to degrade dimethoate was $28^{\circ}$ C. L. sphaericus DM-3 and B. cereus DM-5 showed maximum growth in the presence of dimethoate at $\mathrm{pH} 6.0$ and 7.0, respectively. L. sphaericus DM-3 could degrade $24 \%$ of dimethoate within 72 $\mathrm{h}$, whereas the degradation percentage using B. cereus DM-5 was $17 \%$ after the same incubation period. The main byproducts from the degradation of dimethoate by $L$. sphaericus DM-3 and B. cereus DM-5 was namely O,O,S-trimethyl phosphorothioate. This study reports for the first time the efficient ability of $L$. sphaericus DM-3 and $B$. cereus DM-5 to degrade dimethoate, up to $500 \mathrm{mg} / \mathrm{L}$, over a wide range of $\mathrm{pH}$.
\end{abstract}

Keywords: Dimethoate, Biodegradation, Lysinibacillus sphaericus, Bacillus cereus.

\section{Introduction}

O,O-dimethyl S-methyl carbamoyl methyl phosphorodithioate (dimethoate) is an anticholinesterase organophosphorus (OP) and carbamate pesticide characterized by the presence of carbamate group in its structure (Li et al., 2010 and Kumar \& Gurupadayya, 2013). Dimethoate exerts its activity on insects by phosphorylation of the enzyme acetylcholinesterase at ending of nerves (Sogorb \& Vilanova, 2002). The insect effector organs are overstimulated by the excess amount of acetylcholine, resulting in muscle contraction, i.e. symptoms of cholinergic poisoning (Vermeire et al., 2001 and Zhang et al. 2012). According to information published by the National Pesticide Information Center (2014), dimethoate is one of the most used OP pesticides worldwide. The continuous use of dimethoate has led to environmental pollution and disturbance in the biological ecosystem because of its toxicity (Chen et al., 2016). The relative high solubility of dimethoate in water indicates its low affinity for most types of soil and thus it has a relatively high potential for movement through farming soils (Van Scoy et al., 2016). Therefore, residues of dimethoate and its toxic analog omethoate were detected in soil and many crops (Al-Haifi et al., 2006).

The US environmental protection agency classified dimethoate as the third contaminant candidate list (CCL3), known to occur in public water systems that may impact human public health (U.S. EPA, 2009). The dimethoate adverse effect on the reproductive system and fertility of male rats was reported as the administration of dimethoate by oral route to adult male rats at the doses of $3.66,5.50$ and $11.00 \mathrm{mg} / \mathrm{kg} / \mathrm{day}$ disrupted spermatogenesis process and reduced the rats fertility (Ngoula et al., 2014). Another study showed the carcinogenicity of dimethoate in male and female rats which developed monocytic leukemia (Reuber, 1984). Furthermore, the long-

\#Corresponding author email: msaleh@sci.cu.edu.eg 
term effects of dimethoate exposure in mouse gastric tissue at low dose have been associated with potential carcinogenicity (Wang et al., 2013). Therefore, many western countries are banning the use of dimethoate such as France, Spain, and Italy (Mandal et al., 2005).

Microorganisms have a major role in environmental restoration throughbiodegradation of many pesticides as they have powerful mechanisms to clean up pesticide-contaminated soils (Essa et al., 2016 and Li et al., 2010). Microorganisms can aid in cleaning up pesticide-contaminated sites by oxidizing, binding, immobilizing, volatilizing or otherwise transforming contaminants through the extracellular enzymes production that act on a wide range of organic compounds (Lovley, 2003 and Ortiz-hernández et al., 2013).

Many attempts have been made for the degradation of dimathoate by microorganisms such as fungi; Aspergillus niger (Liu et al., 2001), Gram-negative bacteria; Sphingomonas sp. (Chen et al., 2016) and Pseudomonas sp. (Deshpande et al. , 2001) as well as Gram-positive bacteria; Paracoccus sp. (Li et al. 2010) and Bacillus species (Mandal et al., 2005 and Jayamadhuri, 2014). The efficiency of microorganisms to degrade pesticides has been reported to depend on several environmental parameters such as pH and temperature (Deshpande et al., 2001 and Ortiz-hernández et al. 2013). Despite many studies have been addressed the microbial degradation of dimethoate, the current understanding about the underlaying mechanisms and the byproducts produced is still fragmentary. Moreover, there is evidence that the microbial degradation of dimethoate is likely produces more toxic byproducts (Yao et al., 2011 and Van Scoy et al., 2016). Therefore, the aim of this study is to explore the soil microbial diversity, searching for new local bacterial isolate capable of degrading dimethoate effectively to less or nontoxic compounds.

\section{Materials and Methods}

Chemicals and cultivation media

High grade Dimethoate ( $99.40 \%$ purity) was purchased from Chem Service (West Chester, USA). Luria-Bertani (LB) medium and mineral salts medium (MS) were purchased from Bio basic (Ontario, Canada).

Isolation of dimethoate-degrading bacterial strains

In order to isolate dimethoate-degrading bacteria, soil samples were collected from the
River Nile banks and agriculture fields treated with dimethoate (Giza, Egypt). The enrichment of the bacteria was done by inoculating ten grams of soil sample in $1000 \mathrm{ml}$ of MS broth supplemented with dimethoate $(100 \mathrm{mg} / \mathrm{L})$ and incubated at $30^{\circ} \mathrm{C}$ for $48 \mathrm{~h}$ in a rotary shaker at $150 \mathrm{rpm}$. One $\mathrm{ml}$ of bacterial culture was serially diluted up to $10^{-6}$ dilution. The enrichment dilutions were plated onto solid MS media supplemented with dimethoate $(100 \mathrm{mg} / \mathrm{L})$ and incubated at $37^{\circ} \mathrm{C}$ for $48 \mathrm{~h}$. Two bacterial isolates were selected, purified and maintained at $4{ }^{\circ} \mathrm{C}$ on nutrient agar slants as well as glycerol stocks at $-20^{\circ} \mathrm{C}$ for further investigation.

\section{Identification of dimethoate-degrading bacterial isolates}

The two potent bacterial isolates were selected, tested for their Gram stain, morphological shape, and spore formation ability under the microscope and identified based on both the morphological and biochemical properties with reference to Bergey's Manual of Determination Bacteriology (Sneath, 1986). The two bacterial isolates were designed as DM-3 and DM-5. Additional molecular confirmation, 16S rRNA gene sequence analysis was performed. Genomic DNA of the two isoltes was extracted using Genomic DNA Kit (GeneJETTM ${ }^{\mathrm{TM}}$,Thermo Scientific, USA) according to kit's instructions. Two PCR primers were used to amplify $16 \mathrm{~S}$ rRNA gene; forward primer 27F (5'-AGAGTTTGATCMTGGCTCAG-3') and reverse primer 1492R (5'-TACGGYTACCTTGTTACGACTT-3'). PCR was carried out as the follow; $25 \mu \mathrm{l} 2 \mathrm{X}$ DreamTaq master mix, $1 \mu \mathrm{l}$ from each primer, 2 $\mu \mathrm{l}$ bacterial gDNA template (ca. $50 \mathrm{ng}$ ) and finally sterile water up to $50 \mu \mathrm{l}$. The PCR program was adjusted to initial denaturation at $95^{\circ} \mathrm{C}$ for $4 \mathrm{~min}$, then denaturation at $95^{\circ} \mathrm{C}$ for $40 \mathrm{sec}$, annealing at $58^{\circ} \mathrm{C}$ for $40 \mathrm{sec}$, extension at $72^{\circ} \mathrm{C}$ for 1.5 min for 25 cycles, and a final extension step at $72^{\circ} \mathrm{C}$ for 10 min using GeneAmp 9700 thermal cycler (Applied Biosystems, USA). The amplicon was purified by PCR Purification kit (Biobasic, Canada). The purified amplicon was sequenced using the same primers by ABI3500 sequencer (Applied Biosystems, USA). The contig sequence was obtained from forward and reverse DNA sequence reads using DNA Baser Sequence Assembler software v.3.5.3. Identification of bacterial was performed by the BLAST server.

\section{Phylogenetic analysis}

The sequences of 16S rRNA gene of both isolates were compared to references of $16 \mathrm{~S}$ rRNA 
gene sequences of other bacterial isolates retrieved from NCBI database. Mega 7.0 software was used to construct the phylogenetic relationship with our isolated strain by neighbor-joining method.

The degradation ability of the two bacterial isolates at different incubation time

A single colony of two bacterial isolates inoculated into two test tubes containing $5 \mathrm{ml} \mathrm{LB}$ medium and incubated overnight at $37^{\circ} \mathrm{C}$ with moderate shaking $(250 \mathrm{rpm})$. Fifty microliters from each culture $\left(10^{5} \mathrm{cfu} / \mathrm{ml}\right)$ were inoculated in different flasks containing $50 \mathrm{ml}$ of MS broth supplemented with $100 \mathrm{mg} / \mathrm{L}$ of dimethoate as a sole carbon source. The growth was measured in terms of turbidity, by monitoring the optical density at $600 \mathrm{~nm}$ using spectrophotometer at different times of incubation lasting from $6 \mathrm{~h}$ to $72 \mathrm{~h}$. The experimental units were performed with three replicates. Control sets without bacterial inoculums were incubated under the same conditions.

Effect of different dimethoate concentrations on the growth of the DM-3 and DM-5

In order to evaluate the capability of the two isolated bacteria to grow and utilize dimethoate, a single colony of DM-3 and DM-5 was inoculated into two test tubes containing $5 \mathrm{ml} \mathrm{LB}$ medium and incubated overnight at $37^{\circ} \mathrm{C}$ with moderate shaking $(250 \mathrm{rpm})$. Fifty microliters from each culture $\left(10^{5} \mathrm{cfu} / \mathrm{ml}\right)$ were inoculated in different flasks containing $50 \mathrm{ml}$ of MS broth supplemented with different concentration of dimethoate (100 to $500 \mathrm{mg} / \mathrm{L}$ ) as a sole carbon source and incubated at $28^{\circ} \mathrm{C}$ for $72 \mathrm{~h}$. The experiment was performed with three sets of replicates. Control sets without bacterial inoculums were incubated under the same conditions. The growth of bacteria in the medium was determined in terms of turbidity in the culture broth, by monitored the optical density at $600 \mathrm{~nm}$ using spectrophotometer

Effect of different temperature and $\mathrm{pH}$ on the growth of dimethoate-degrading bacteria

Fifty microliters from each overnight grown culture $\left(10^{5} \mathrm{cfu} / \mathrm{ml}\right)$ were inoculated in different flasks containing 15 milliliters of MS media supplemented with $100 \mathrm{mg} / \mathrm{L}$ of dimethoate as sole carbon source. The $\mathrm{pH}$ was adjusted to different $\mathrm{pH}$ ranging from $(4-12)$. The flasks were incubated on a rotary water bath shaker at room temperature and $200 \mathrm{rpm}$ for $72 \mathrm{~h}$. Depending on the optimal $\mathrm{pH}$; the temperature values were adjusted to 15 , $18,37,50$ and $70^{\circ} \mathrm{C}$ with previously mentioned procedures and conditions. Control sets without bacterial inoculums were incubated under the same conditions. The growth of bacteria in the medium was determined in terms of turbidity in the culture broth, by monitoring the optical density at $600 \mathrm{~nm}$ :

Quantification of dimethoate residues using high performance liquid chromatography (HPLC)

Both bacterial isolates were grown overnight in LB medium, $10 \mu \mathrm{l}$ of each bacterial culture was inoculated into $10 \mathrm{ml} \mathrm{MS}$ medium containing 100 $\mathrm{mg} / \mathrm{L}$ of dimethoate and incubated in an orbital shaker at $28^{\circ} \mathrm{C}$ for $72 \mathrm{~h}$ as separate treatment. Samples were prepared referred to (Kumar \& Gurupadayya, 2013). The concentration of utilized dimethoate was determined by high performance liquid chromatography (HPLC) (Binary LC Pump, USA). Standard (without inoculation of bacterial strain) was used to compare the inoculated samples. The separation was accomplished using Phenomenexluna C18 column. The solvent system was acetonitrile:water $(60: 40 \mathrm{v} / \mathrm{v})$ at a flow rate 1 $\mathrm{ml} / \mathrm{min}$, and the volume of the sample injected was $20 \mu 1$.

Identification of the metabolites resulting from the degradation of dimethoate by gas chromatography/ mass spectrometric (GC/MS) analysis

The two bacterial strains DM-3 and DM-5 grown overnight in LB medium, $10 \mu \mathrm{l}$ of both bacterial cultures was inoculated into $15 \mathrm{ml} \mathrm{MS}$ medium containing $100 \mathrm{mg} / \mathrm{L}$ of dimethoate and incubated in an orbital shaker at $28^{\circ} \mathrm{C}$ for 7 days under optimized conditions. Metabolites formed from dimethoate degradation by each bacterial isolates were determined separately using $\mathrm{GC}$ MS equipped with an Aligent mass spectrometric detector, with a direct capillary interface and fused silica capillary column PAS-5 ms $(30 \mathrm{~m} \times 0.32$ $\mathrm{mm} \times 0.25 \mu \mathrm{m}$ film thicknesses). An equal volume dichloromethane was added to extract the residual dimethoate. After vigorous shaking for $5 \mathrm{~min}$, the organic layer was separated and dehydrated by passing through anhydrous $\mathrm{Na}_{2} \mathrm{SO}_{4}$. Pulsed split in less-mode option was used to analyze samples at $280^{\circ} \mathrm{C}$ injection temperature. The carrier gas was helium at flow rate of ca. $1.0 \mathrm{ml} / \mathrm{min}$. The solvent delay was $3 \mathrm{~min}$ and $1.0 \mu \mathrm{l}$ injected. The electron multiplier voltage was maintained $1650 \mathrm{v}$. The GC/MS operation parameters were as follows: ionization potential $70 \mathrm{eV}$, interface temperature was $230^{\circ} \mathrm{C}$, and acquisition mass range scanning ranged from $50 \mathrm{~m} / \mathrm{z}$ to $500 \mathrm{~m} / \mathrm{z}$. The instrument was tuned using perfluorotributylamine. GC column oven temperature was programmed for an initial hold of $2 \mathrm{~min}$ at $60^{\circ} \mathrm{C}$ and the temperature was increased to $300^{\circ} \mathrm{C}$, the rate was $5^{\circ} \mathrm{C} / \mathrm{min}$. 
The identification of components was assigned by a comparison of their mass spectra and retention time with those of the authentic compounds and by matching with NIST, W9N11 and RTLPEST3 library.

\section{Statistical analysis}

Data were represented in figures as mean of replicates from three independent experiments and were analyzed for statistical difference using either Student's t-test or Duncan's test (SigmaStat version 3.5). Significant differences were based on the value of $\mathrm{p} \leq 0.05$.

\section{Results}

Identification and characterization of the culture strain

\section{Morphological identification}

The isolation and enrichment techniques yielded two bacterial strains, designated as DM-3 and DM5 , demonstrated the ability to utilize and grow in MS media supplied with $100 \mathrm{mg} / \mathrm{L}$ of dimethoate as sole carbon source. Based on morphological and biochemical results, the two isolates were initially identified as Lysinibacillus sphaericus DM-3 (formerly known as Bacillus sphaericus) and Bacillus cereus DM-5. The morphological characteristics showed that the two strains have colonies that are different in shape and appearance. The results of microscopic examination revealed that both isolates are Gram-positive, rod-shaped and spore-forming bacteria. The biochemical tests revealed that both strains are motile, can grow at $5 \% \mathrm{NaCl}$, utilize citrate and glycerol, hydrolyzed casein, show hemolysis on blood agar media, did not produce pigments or indole and cannot hydrolyze the gelatin (Table 1). Unlike B. cereus DM-5, L. sphaericus DM-3 cannot grow at $45^{\circ} \mathrm{C}$, failed to hydrolyze urea, ferment starch or utilize fructose. On the other hand, oxidase activity was only observed in L. sphaericus DM-3.

Molecular identification and phylogenetic
analysis
The corresponding PCR amplicons of $16 \mathrm{~S}$ rRNA of both strains were visualized on $1.5 \%$ agarose. Amplification of 16S rRNA and sequencing produced 1438 bp and 1432 bp fragments for DM-3 and DM-5, respectively. All the sequences were edited manually and trimmed to remove ambiguous region. The sequences were analyzed and submitted to GenBank under accession number MF967404 and MF967405 for DM -3 and DM- 5, respectively.

The sequences were aligned by multiple sequence alignment with other bacterial isolates and phylogenetic tree was constructed using Mega
7.0 software (Fig. $1 \mathrm{a}, \mathrm{b}$ ), the phylogenetic analysis revealed that sequence of strain DM-3 showed 99\% similarities with 16S rRNA sequence of Lysinibacillus $\mathrm{sp}$. The biochemical tests results revealed that strain DM-3 was closest to Lysinibacillus sphaericus (Coorevits et al., 2012) Whereas the strain DM-5 showed 99\% similarities with 16S rRNA sequence of Bacillus cereus.

The growth curve of both bacterial strains in presence of dimethoate

The growth of both strains showed a steady increase up to $36 \mathrm{~h}$, which barely increased afterward (Fig. 2). During the exponential phase of growth the cell density of $L$. sphaericus DM-3 increased from 0.2 to 1.16 (OD $600 \mathrm{~nm}$ ), while that for $B$. cereus DM-5 elevated from 0.1 to 1.10 (OD $600 \mathrm{~nm}$ ). Moreover, the growth of L. sphaericus DM-3 was significantly higher than that for $B$. cereus DM-5 at most of time points.

Utilization of dimethoate by the degrading bacteria in different concentrations of dimethoate

The results indicate the ability of both strains to utilize different concentration range $(100-500 \mathrm{mg} / \mathrm{L})$ of dimethoate (Fig.3). The highest bacterial growth was recorded at the concentration of $100 \mathrm{mg} / \mathrm{L}$. Furthermore, both strains were able to tolerate high dimethoate concentration up to $500 \mathrm{mg} / \mathrm{L}$ as indicated by the increase in cell density to 0.77 and 0.62 (OD $600 \mathrm{~nm}$ ) by L. sphaericus DM-3 and B. cereus DM-5, respectively (Fig.3). There was a gradual significant reduction in $B$. cereus DM-5 growth proportionate with the increase in dimethoate concentration. However, there was no significant reduction in the growth of $L$. sphaericus DM-3 between both ranges 200-300 and 300-400 $\mathrm{mg} / \mathrm{ml}$ of dimethoate.

Effect of different $\mathrm{pH}$ and temperature on bacterial growth in the presence of dimethoate

The results indicated that both bacterial strains could grow at $\mathrm{pH}$ range from 4 to 12 (Fig. 4 a). The optimal $\mathrm{pH}$ of L. sphaericus DM-3 and $B$. cereus DM-5 was 6 and 7, respectively. There was a significant reduction in the growth due to change in $\mathrm{pH}$, acidic or alkaline, compared with optimum $\mathrm{pH}$ for each strain. L. sphaericus DM-3 and B. cereus DM-5 utilized dimethoate efficiently at a broad range of temperatures from 15 to $37^{\circ} \mathrm{C}$ (Fig. 4 b). The optimal temperature for both strains was $28^{\circ} \mathrm{C}$. L. sphaericus DM-3 showed significant reduction in growth after further increase in temperature higher than $37^{\circ} \mathrm{C}$, whereas $B$. cereus DM-5 tolerated the increase in temperature showing no significant change in growth between the range $37-70^{\circ} \mathrm{C}$. 
TABLE 1. Morphological characteristics of colony and biochemical characterization of the two dimethoatedegrading bacteria

\begin{tabular}{lll} 
Test & L. sphaericus DM-3 & B. cereus DM-5 \\
\hline
\end{tabular}

Colony morphological

- Shape

$\begin{array}{cc}\text { filamentous } & \text { round } \\ \text { white } & \text { yellow } \\ \text { flat } & \text { flat }\end{array}$

- Color

flat

flat

\section{Biochemical characterization}

Gram stain

Endospore formation

Shape

rod

$\operatorname{rod}$

Motility

$\begin{array}{lr}+ & + \\ + & + \\ & \operatorname{rod} \\ + & +\end{array}$

Pigment

Blood hemolysis

-

Growth at $45^{\circ} \mathrm{C}$

Growth in $5 \% \mathrm{NaCl}$

Growth at pH 6

Hydrolysis of urea

Hydrolysis of gelatin

Hydrolysis of casein

Nitrate reduction

Oxidase

Utilization of citrate

Utilization of Fructose

Utilization of glycerol

Indole production

Fermentation of starch

$+$

-

$+\quad+$

$+$

$+$

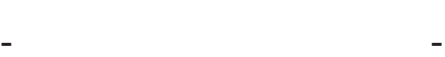

$+\quad+$

$+\quad-$

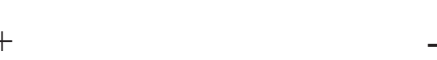

+

-

$+$

+ , positive reaction; -, negative reaction. 

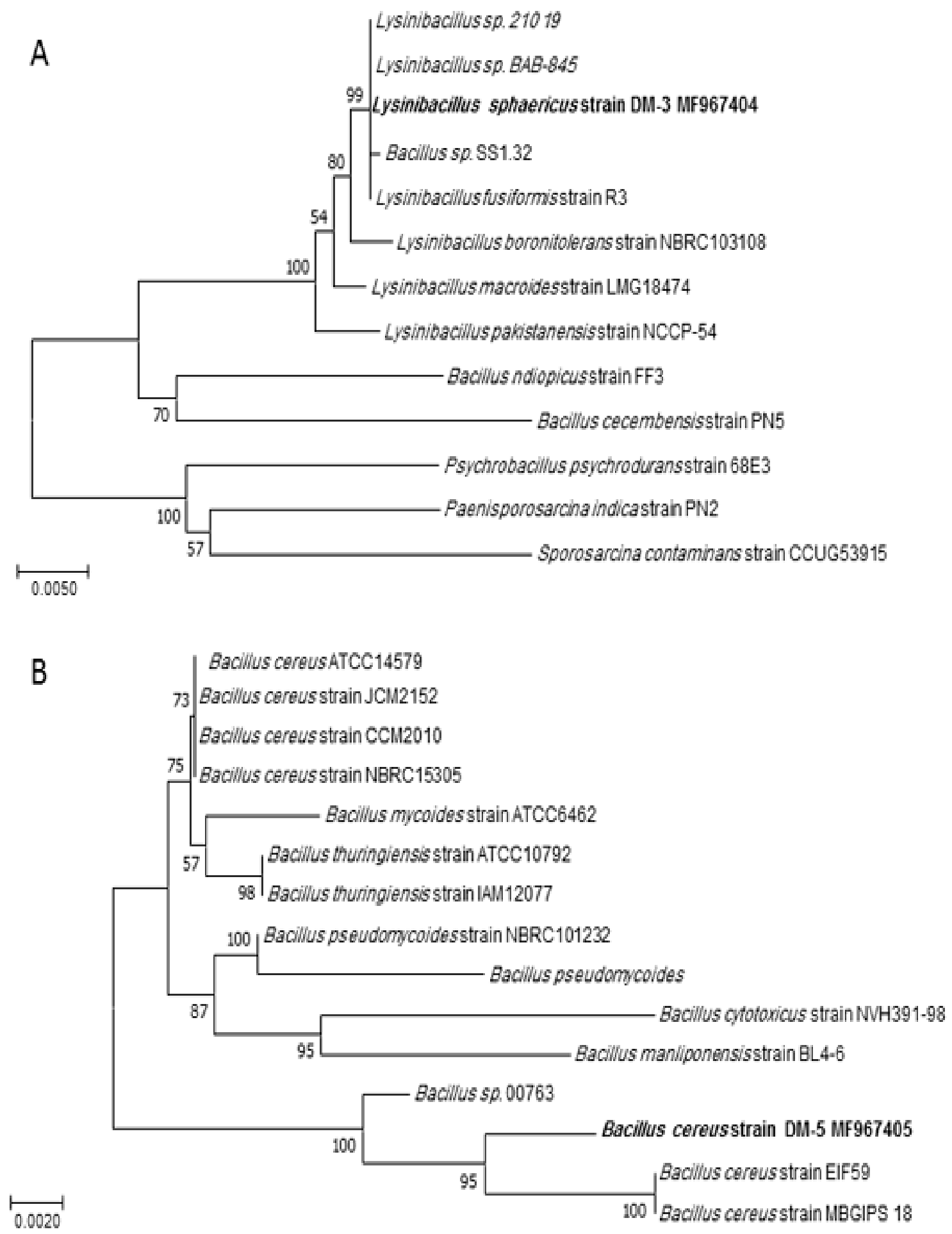

Fig. 1. 16S rRNA sequences based phylogenetic tree showing the phylogenetic relationship of both strains of $L$. sphaericus DM-3 (A) and B. cereus DM-5 (B) with different bacterial strains. Two phylogenetic trees were constructed by the neighbour-joining method using Mega 7.0 software. Numbers at nodes represents branch length. Bars represent nucleotide substitution per nucleotide position. 


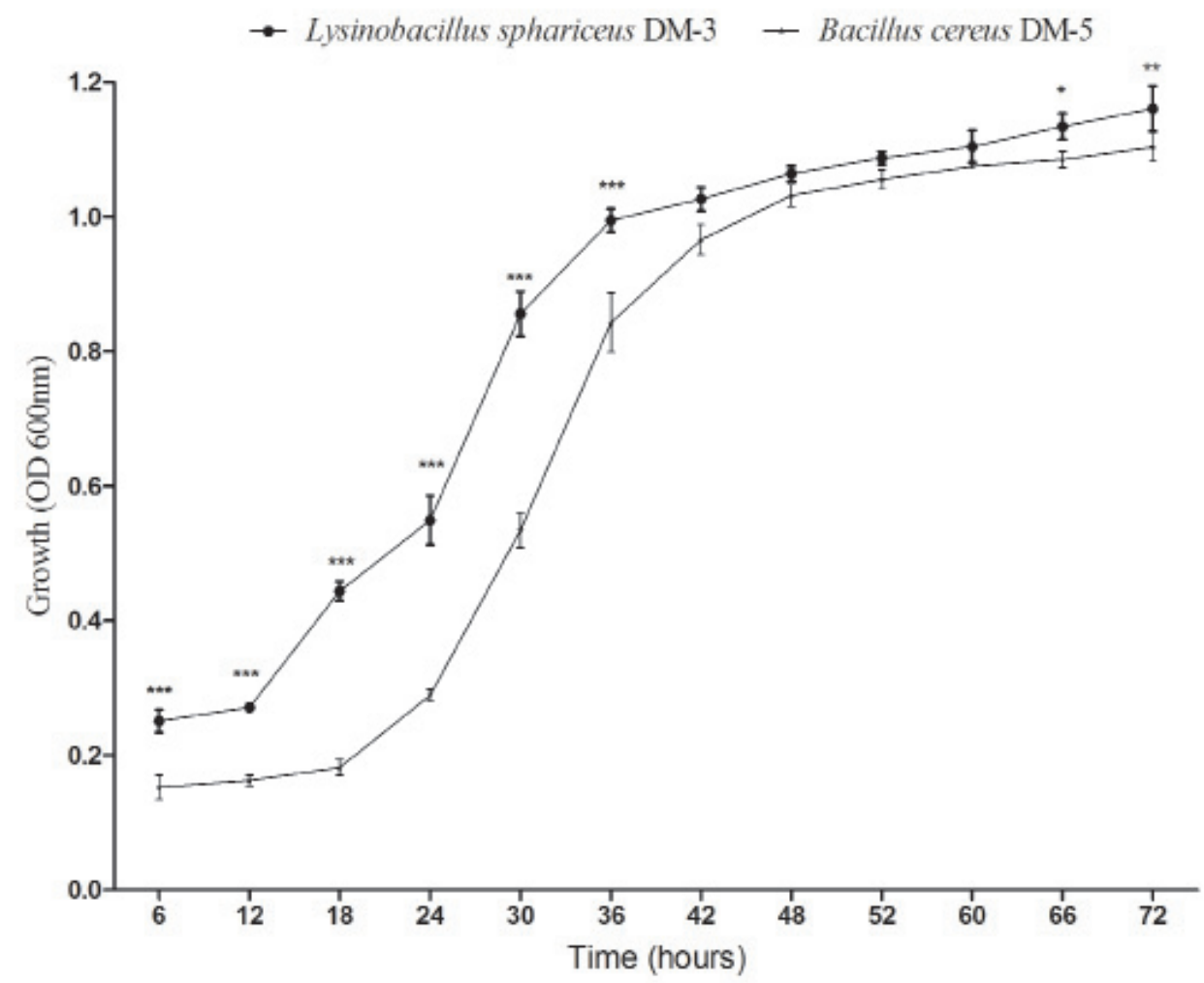

Fig. 2. The time course of the growth of $L$. sphaericus DM-3 and B. cereus DM-5 in MS containing dimethoate at the rate of $100 \mathrm{mg} / \mathrm{L}$. Data were presented as mean of replicates and were analyzed statistically using Student's t-test for independent samples. *** $\mathrm{p} \leq 0.001 ; * * \mathrm{p} \leq 0.01 ; * \mathrm{p} \leq 0.5$.

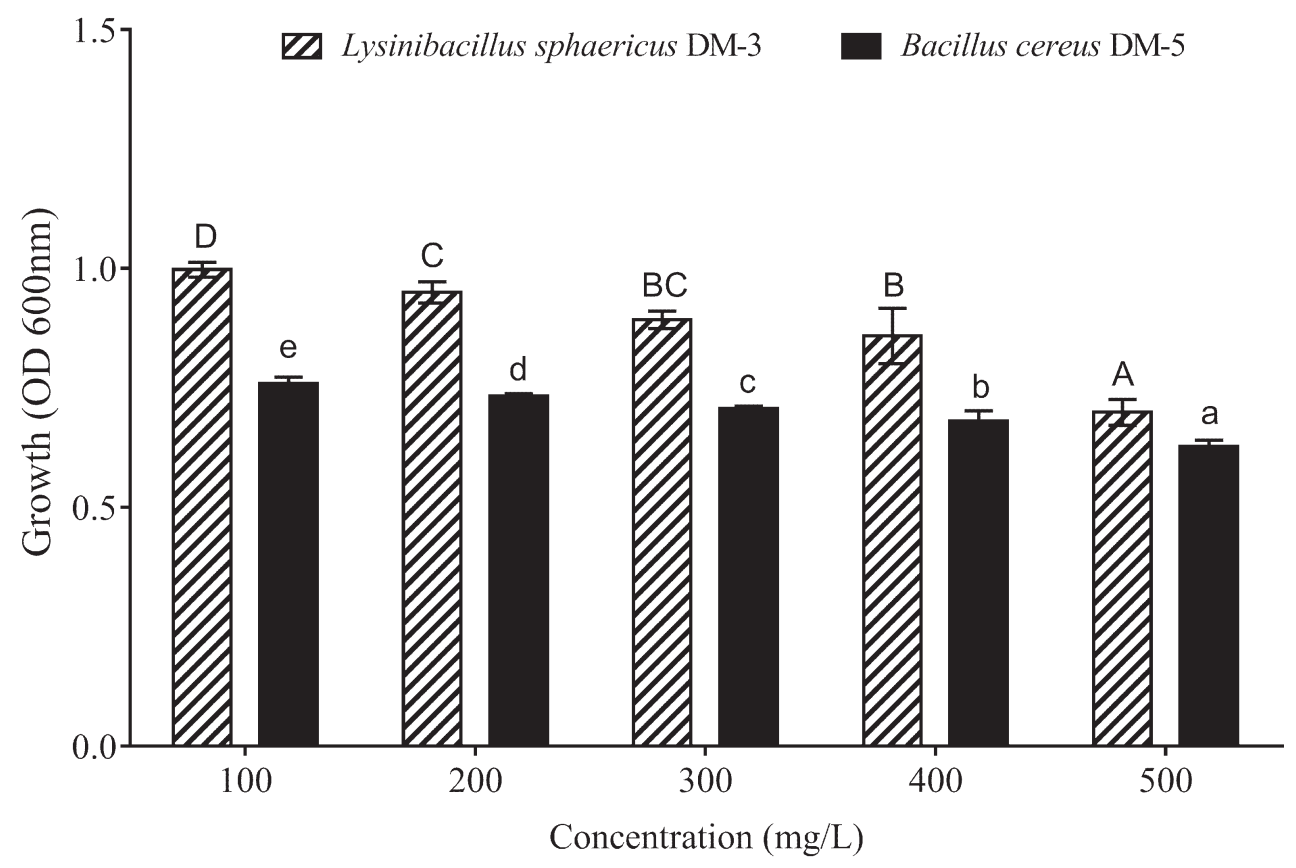

Fig. 3. Effect of different dimethoate concentrations (100-500 mg/L in MS media) on bacterial growth of $L$. sphaericus DM-3 and B. cereus DM-5. The data are represented as the mean \pm standard deviation and analyzed statistically using Duncan's tests. Different letters on the bars indicate significant difference within the same strain, whereas bars with common letter are not significantly different. Upper case letters are for $\boldsymbol{L}$. sphaericus DM-3 and lower case letters are for B. cereus DM-5. 
A

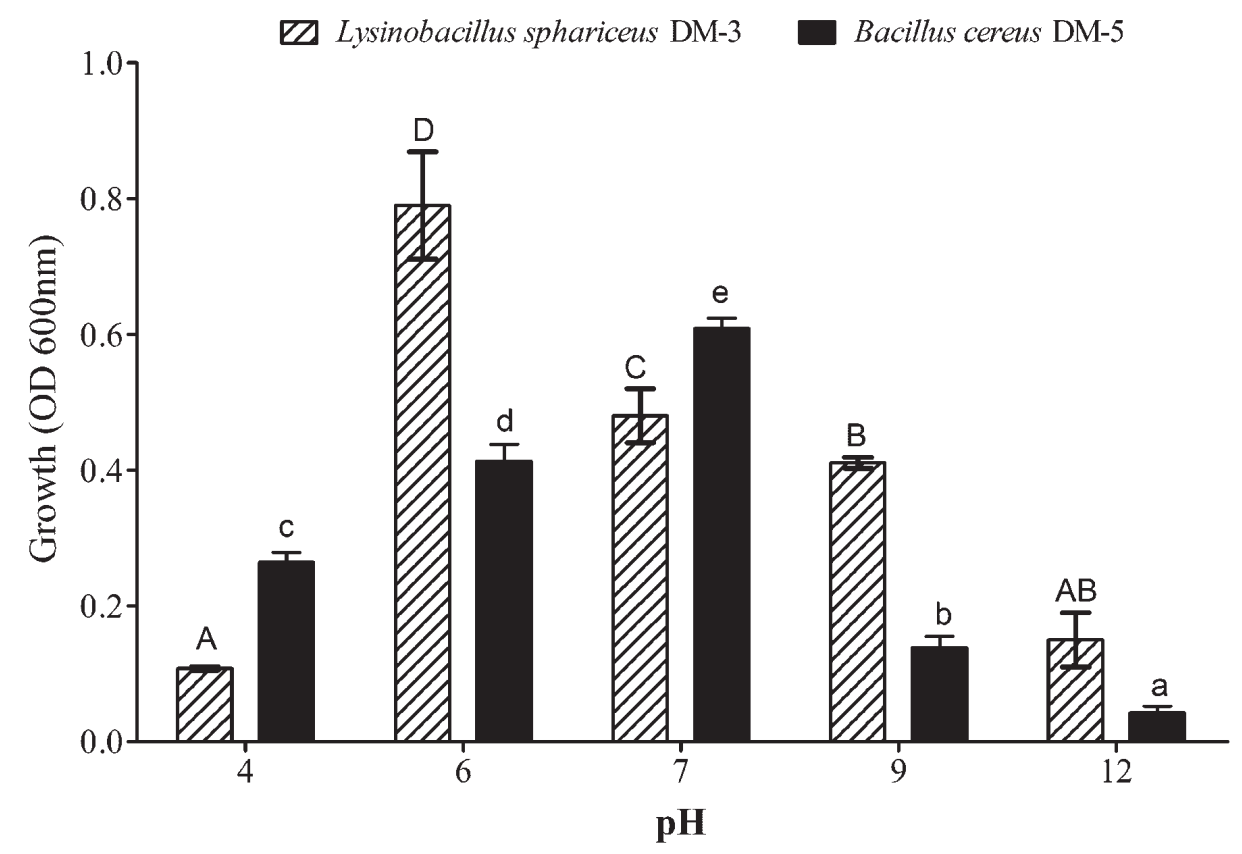

B

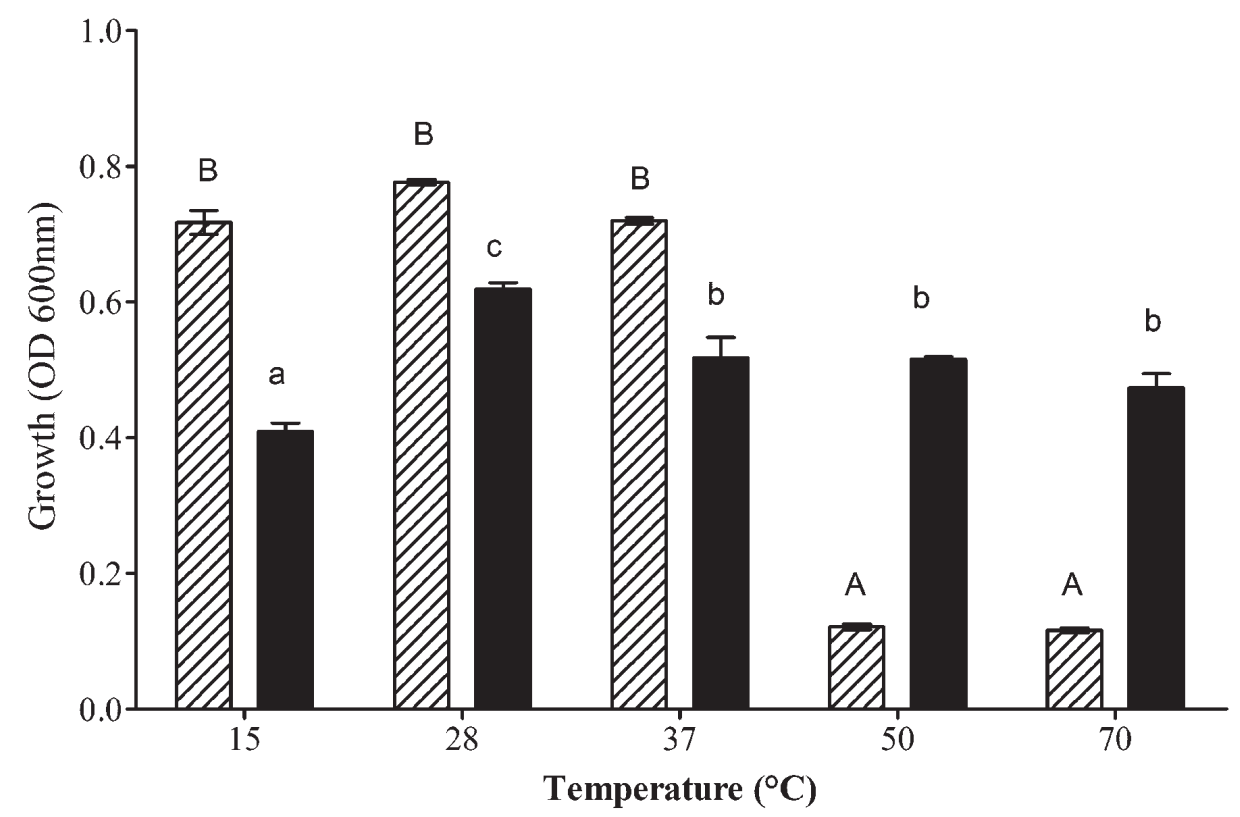

Fig. 4. Effect of changing pH (A) and different temperature (B) values on growth of $L$. sphaericus DM-3 and $B$. cereus DM-5 in the presence of dimethoate $(100 \mathrm{mg} / \mathrm{L})$ as a sole carbon source. The data are represented as the mean \pm standard deviation as analyzed statistically using Duncan's tests. Different letters on the bars indicate significant difference within the same strain, whereas bars with common letter are not significantly different. Upper case letters are for $L$. sphaericus DM-3 and lower case letters are for B. cereus DM-5. 
Quantification of dimethoate residues using High Performance Liquid Chromatography (HPLC)

The HPLC profile of MS media supplemented with $100 \mathrm{mg} / \mathrm{L}$ of dimethoate (positive control, Fig.5 a) showed 7 peaks with retention time (RT) of 1.46, 1.93, 2.43, 2.95, 3.80, 6.11 and 6.8 min (Fig.5 b). The HPLC profile obtained for the two bacteria treated samples significantly differed from the control in terms of number and height of peaks obtained and their RT. The HPLC profile of dimethoate treated with $L$. sphaericus DM-3 showed 4 peaks different from the control with RT 2.72, 3.52, 5.33 and 8.80 min (Fig.5 d). While the sample treated with $B$. cereus DM-5 showed two peaks different from the control with RT 1.91 and $2.71 \mathrm{~min}$ (Fig.5 c). These results suggested that there are degradation products are formed by action of both bacterial strains. The dimethoate concentration was reduced from the initial concentration $0.1 \mathrm{mg} / \mathrm{ml}$ to $0.076(24 \%$ degradation) for L. sphaericus DM-3 and 0.083 $\mathrm{mg} / \mathrm{ml}$ (17\% degradation) for B. cereus DM-5, after 3 days of incubation.
A

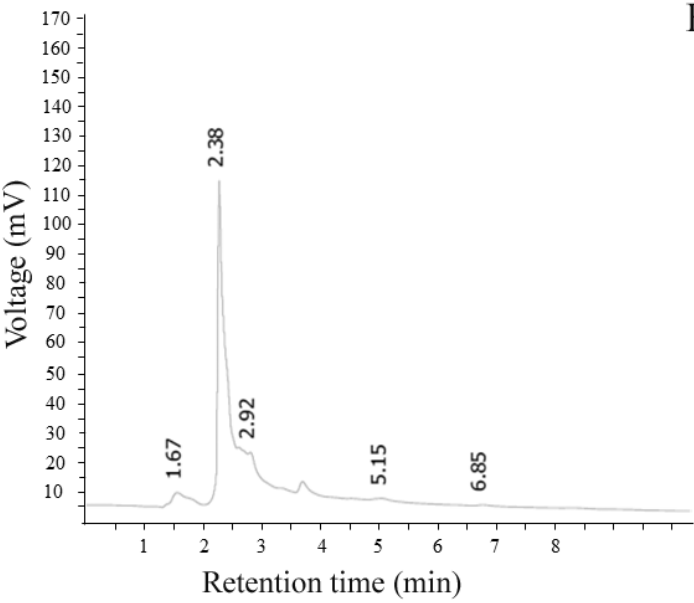

C

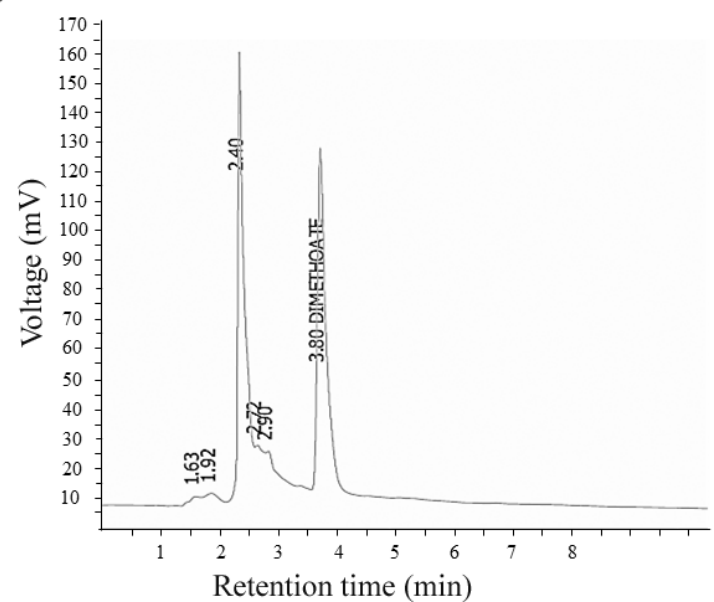

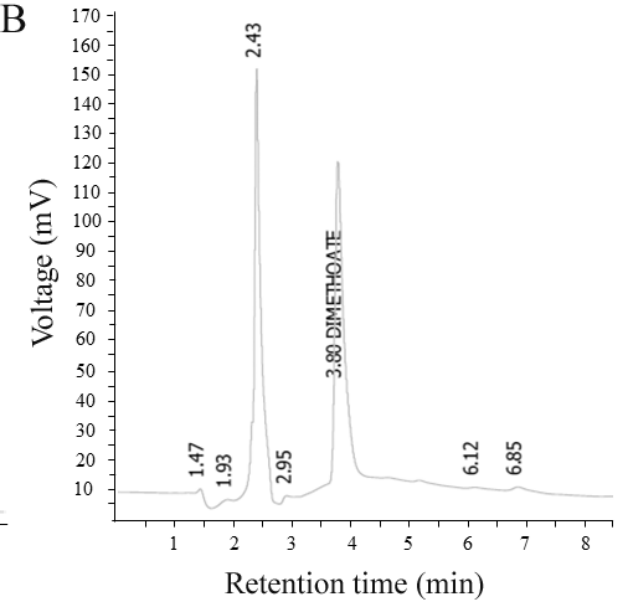

$\mathrm{D}$

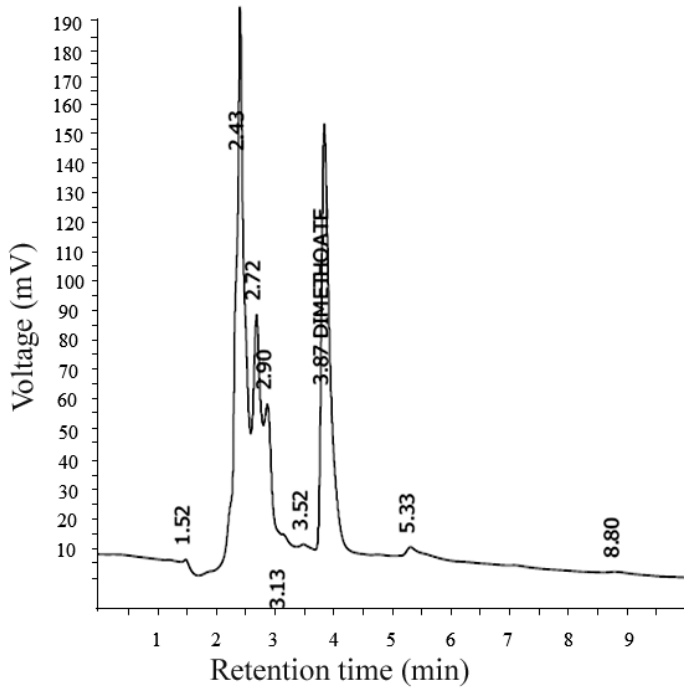

Fig. 5. Quantification of dimethoate degradation by L. sphaericus DM-3 and B. cereus DM-5 using HPLC analysis. Samples were prepared by inoculation of both strains in MS media supplemented with 100 $\mathrm{mg} / \mathrm{L}$ dimethoate and $72 \mathrm{~h}$ of incubation. A) Control chromatogram of MS media without dimethoate B) Control chromatogram of MS media supplemented with $100 \mathrm{mg} / \mathrm{L}$ dimethoate C) HPLC chromatogram of MS media supplemented with $100 \mathrm{mg} / \mathrm{L}$ dimethoate and inoculated by B. cereus DM-5 D) HPLC chromatogram of MS media supplemented with $100 \mathrm{mg} / \mathrm{L}$ dimethoate and inoculated by $L$. sphaericus DM-3. 
Identification of the metabolites resulting from the degradation of dimethoate using GC/MS

The metabolites produced during the degradation of dimethoate by L. sphaericus DM-3 and $B$. cereus DM-5 after 7 days of incubation, were detected using GC/MS. The spectrum patterns of dimethoate degrading residues by both strains were shown in Fig. 6. The GC/MS analysis of dimethoate degradation indicates that there were a considerable number of peaks. All the compounds were identified either according to NIST, W9N11 and RTLPEST3 library. Chemical names and retention times of the compounds produced by both strains are summarized in Tables 2 and 3. A peak with a retention time 10.54 was identified as O,O,S-trimethyl phophorothioic acid, was found to be the sole compound related to the biodegradation of dimethoate (Yao et al., 2011) in both strains with a $93 \%$ matching probability with W9N11 library. Many bacterial metabolic compounds, not related to dimethoate degradation, were detected in aqueous fractions of both strains such as oleic acid detected in L. sphaericus DM-3 (Table 2). The toxic metabolite, omethoate, was not detected in the aqueous extract of both strains.
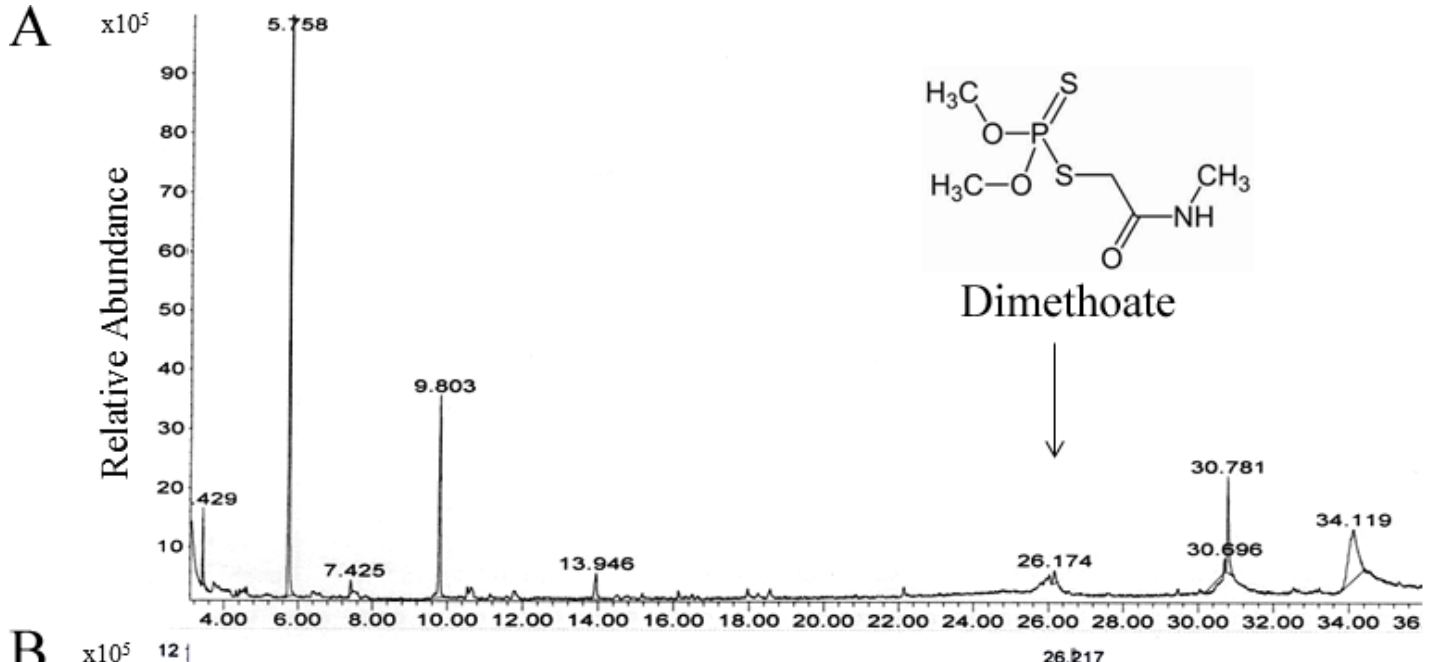

B

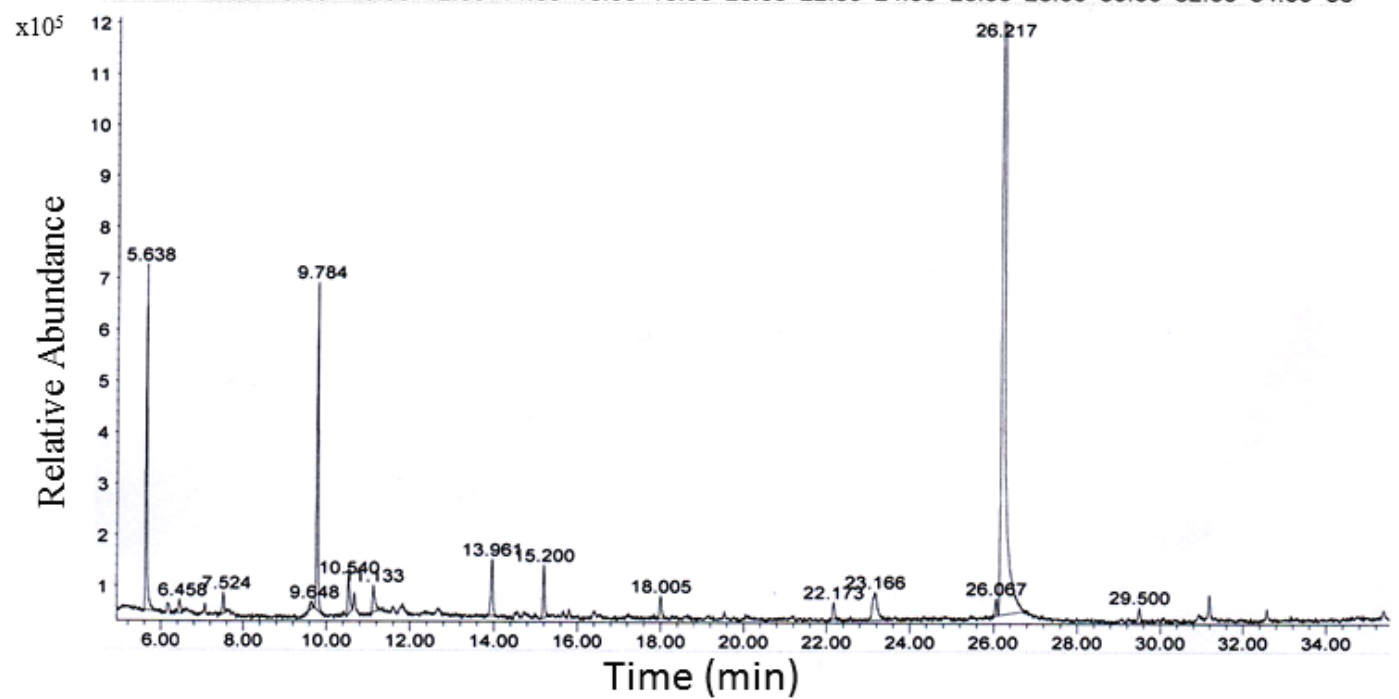

Fig. 6. Separation of metabolites resulting from dimethoate degrading strains $L$. sphaericus DM-3- and B. cereus DM-5 by GC/MS. Samples were prepared by inoculation of both strains in MS media supplemented with $100 \mathrm{mg} / \mathrm{L}$ dimethoate and incubated for 7 days. A) Metabolites produced due to degradation of dimethoate by $L$. sphaericus DM-3; B) Metabolites produced due to degradation of dimethoate by B. cereus DM-5. The metabolites were identified according to NIST, W9N11 and RTLPEST3 library. 
TABLE 2. The compounds detected by GC/MS in the aqueous fraction of culture filtrate of $L$. sphaericus DM-3 grown in MS broth supplemented with dimethoate.

\begin{tabular}{|c|c|c|c|c|c|}
\hline Isolate & No. & Chemical Name & $\begin{array}{c}\text { RT } \\
(\min )\end{array}$ & $\begin{array}{c}\text { Area } \\
(\%)\end{array}$ & Quality \\
\hline & 1 & $\begin{array}{l}\text { Silanediol,dimethyl-dihyroxydimethylsilane, } \\
\text { dimethylsilanediol }\end{array}$ & 3.427 & 1.93 & 87 \\
\hline & 2 & 2-Amino-6methylbenzoic acid, 6-amino-o-toluic acid & 5.761 & 32.70 & 64 \\
\hline & 3 & Cyclotetrasiloxane, octamethyl & 7.425 & 0.52 & 72 \\
\hline & 4 & Tetrasiloxane,decamethyl, decamethyltetrasiloxane & 9.802 & 11.44 & 78 \\
\hline & 5 & Cyclotetrasiloxane, octamethyl, & 13.945 & 2.36 & 87 \\
\hline & 6 & Dimethoate & 26.177 & 1.06 & 96 \\
\hline & 7 & 2-pentene,2-cyano-3-diethylboryl amino & 30.693 & 2.18 & 43 \\
\hline & 8 & Meta-Methoxybenzenethiol m-methoxythiophenol & 30.778 & 6.32 & 58 \\
\hline & $8^{*}$ & O,O,S-trimethyl phophorothioic acid & 10.540 & 0.91 & 93 \\
\hline & 9 & Oleic Acid 9 octadecenoic acid (z) & 34.123 & 17.10 & 99 \\
\hline \multirow[t]{9}{*}{$\begin{array}{l}\text { Lysinibacillus } \\
\text { sphaericus DM-3 }\end{array}$} & 10 & Hexanediooic acid, bis(2ethylhexyl) ester & 38.529 & 1.04 & 64 \\
\hline & 11 & 3,5,7-trimethyl-1-azaadamanatan-4,6,10-trione & 39.004 & 1.44 & 25 \\
\hline & 12 & $\begin{array}{l}\text { 3,4,3a,4,7,7a-Hexahyro-5,6-bis(methoxymethoxy)-2- } \\
\text { phenyl-4-[3-phenyl-1-(trimethy }\end{array}$ & 39.318 & 19.13 & 37 \\
\hline & 13 & Bis (2-ethylhexyl) phthalate & 40.905 & 1.87 & 83 \\
\hline & 14 & Cyclodecasiloxane, eicosamethyl- & 41.236 & 1.16 & 58 \\
\hline & 15 & $\begin{array}{l}\text { 7,8,17,18-tetrahydro-35-methoxy-1,3,21,23- } \\
\text { tetramethyl-16H,31H-5,9.15.19-dimethan }\end{array}$ & 42.535 & 1.68 & 59 \\
\hline & 16 & 1,2-Bis (trimethylesilyl) benzene & 43.333 & 0.85 & 44 \\
\hline & 17 & $\begin{array}{l}\text { 23,24-Dicarbomethoxy-9,10-dimethoxyundecacyclo } \\
{[16 \cdot 10 \cdot 1,1(4,15) \cdot 1(21,26) \cdot 0(2,17) .}\end{array}$ & 43.452 & 0,95 & 46 \\
\hline & 18 & $\begin{array}{l}\text { 2',4'-Dimethyloxaneilic acid N'- } \\
\text { veratrylidenehydrazide }\end{array}$ & 45.294 & 0.95 & 46 \\
\hline
\end{tabular}


TABLE 3. The compounds detected by GC/MS in the aqueous fraction of culture filtrate of $B$. cereus DM-5 grown in MS broth supplemented with dimethoate.

\begin{tabular}{|c|c|c|c|c|c|}
\hline Isolate & No. & Chemical Name & $\begin{array}{c}\text { RT } \\
(\min )\end{array}$ & $\begin{array}{c}\text { Area } \\
(\%)\end{array}$ & Quality \\
\hline & 1 & 3,5-Dihyroxybenzamide & 3.698 & 0.78 & 59 \\
\hline & 2 & $\begin{array}{l}\text { Cyclotrisiloxane, hexamethyl } \\
1,1,3,3,5,5 \text {-Hexamethyl-cyclohexasiloxane }\end{array}$ & 3.885 & 2.55 & 72 \\
\hline & 3 & 5,8-epoxy-15-nor-labdane & 4.386 & 1.60 & 81 \\
\hline & 4 & $\begin{array}{l}\text { Oxime, methoxy, phenyl-methyl } \\
\text { N-hydroxybenzenecarboximidoate }\end{array}$ & 5.642 & 8.17 & 83 \\
\hline & 5 & Trisiloxane, 1,1,3,3,5,5-hexamethyl & 6.457 & 0.70 & 49 \\
\hline & 6 & Cyclotetrasiloxane, octamethyl & 7.527 & 0.78 & 74 \\
\hline & 7 & Cyclotrisiloxane, hexamethyl & 9.649 & 0.04 & 59 \\
\hline & 8 & $\begin{array}{l}\text { Cyclotisiloxane,hexamethyl-1,1,3,3,5,5-Hexamethyl- } \\
\text { cycloHexasiloxane }\end{array}$ & 9.785 & 9.48 & 83 \\
\hline & 9 & O,O,S-trimethyl phophorothioic acid & 10.540 & 1.41 & 93 \\
\hline \multirow[t]{10}{*}{$\begin{array}{l}\text { Bacillus } \\
\text { cereus DM-5 }\end{array}$} & 10 & 4-ethylbenzamide & 11.135 & 1.02 & 49 \\
\hline & 11 & Cyclotetrasiloxane,octamethyl-AS & 13.961 & 2.23 & 74 \\
\hline & 12 & 2- $p$-Nitrophenyl-oxadiazol-1,3,4-one-5 & 15.201 & 1.81 & 53 \\
\hline & 13 & $\begin{array}{l}\text { Cyclopentasiloxane, decamethyl } \\
\text { dimethysiloxanepentamer }\end{array}$ & 18.002 & 1.14 & 90 \\
\hline & 14 & Cyclohexasiloxane,dodecamethyl & 22.170 & 0.74 & 46 \\
\hline & 15 & 1,2-benzenedicarboxylic acid, diethyl ester ethyl phthalate & 23.163 & 2.83 & 93 \\
\hline & $15^{\prime}$ & Diethyl phthalate & 23.163 & 2.83 & 96 \\
\hline & 16 & $\begin{array}{l}\text { 4-dimehylamino)phenyl-4'-(N-methyl)(N-ethyl) } \\
\text { aminophenyl-imine }\end{array}$ & 26.067 & 0.41 & 53 \\
\hline & 17 & Dimethoate & 26.219 & 63.44 & 97 \\
\hline & 18 & Isoproterenol tri-TMS derivative & 29.496 & 0.89 & 27 \\
\hline
\end{tabular}




\section{Discussion}

Organophosphorus insecticides like dimethoate are considered potentially hazardous and have been known to cause several adverse effects on humans and other non-target organisms (Wang et al., 2013 and Qayoom et al., 2016). In this regard, microbial remediation of sites contaminated with chemical pesticides provides a robust and low cost removal process (BaezRogelio et al., 2017). Therefore, many studies were conducted to isolate bacterial strains capable of degrading OP compounds from contaminated soils (Wan et al., 2010; Chanika et al., 2011 and Geed et al., 2016).

In the present study, two dimethoate-degrading strains identified as L. sphaericus DM-3 and B. cereus DM-5 were isolated from dimethoate contaminated soil. The two degrading bacterial candidates were Gram-positive and endospore forming. This was a promising outcome as Grampositive bacteria have a stronger cell envelope than Gram-negative bacteria. It was reported that bacterial endospore production ability is an adaptation mechanism for survival found in Bacillus species (Francis \& Tebo, 2002). This may allow our two strains $L$. sphaericus DM-3 and $B$. cereus DM-5 to thrive in the highly variable environmental conditions.

The previously recorded bacteria degrading OP compounds are mainly Bacillus species, such as B. licheniformis, B. pumilus, B. safensis, $B$. subtilis and B. cereus (Mandal et al., 2005; Singh et al., 2006; Khan et al., 2016 and Begum et al., 2016). On contrary, few studies have pointed to the role of Lysinibacillus spp. in the degradation of pollutants (Wan et al., 2010; Manchola \& Dussan, 2014 and Geed et al. 2016). To our knowledge, this is the first study to report the role of Lysinibacillus spp. in the degradation of dimethoate.

The degradation of dimethoate is affected by a large number of environmental factors (Deshpande et al., 2001). The $\mathrm{pH}$ value is an important factor that influences the microbiological metabolic activity and growth of microorganisms. Different microorganisms can grow over a wide $\mathrm{pH}$ range and every organism has its own tolerance level (Darsa et al., 2014). It was reported that dimethoate degrading-bacteria have optimum growth at $\mathrm{pH}$ ranges from 6 to 9 with maximum growth at $\mathrm{pH}$ 7 (Li et al., 2010 and Chen et al., 2016). Herein, L. sphaericus DM-3 and B. cereus DM-5 showed ability to degrade dimethoate within a broad range of $\mathrm{pH} 4-12$. In general, neutral to slightly alkaline conditions are considered more favorable for bacterial metabolic activities and growth than acidic conditions (Padan et al., 2005).

Another factor that influences the growth and efficiency of pollutants-degrading bacteria is temperature. In this context, the rate of biodegradation mainly ceases at higher temperatures since the degradative enzymes are mostly plasmid-borne and bacterial cells are known to lose their plasmids at high temperatures (Deshpande et al., 2001). Furthermore, there are some evidences that bacterial incubation at $45^{\circ} \mathrm{C}$ may inhibit the synthesis of proteins that are required for survival of germinated spores at elevated temperature (Johnson \& Busta, 1984). This is in line with our results which revealed that L. sphaericus DM-3 efficiently degrade dimethoate at temperatures ranging from 15 to $37^{\circ} \mathrm{C}$ and showed no significant growth at temperature higher than $37^{\circ} \mathrm{C}$, suggesting that $L$. sphaericus DM-3 could have a plasmid encoding degradative enzymes. In contrast, $B$. cereus DM-5 showed the ability to degrade dimethoate at temperature above $37^{\circ} \mathrm{C}$ which indicate the high temperature tolerance of $B$. cereus DM- 5 over $L$. sphaericus DM-3. In accordance with our results, Saleem et al. (2014) reported that B. cereus was effective in the decolonization of the industrial effluents at optimum $\mathrm{pH} 6.5$ and temperature $45^{\circ} \mathrm{C}$.

The utilization of dimethoate as the sole carbon source by bacteria has been reported in many studies (Deshpande et al., 2001 and DebMandal et al., 2008). The current study demonstrated that L. sphaericus DM-3 and B. cereus DM-5 could degrade dimethoate similar or even higher than previously reported bacterial strains. Both strains showed the ability to utilize $100 \mathrm{mg} / \mathrm{L}$ of dimethoate effectively and tolerate the presence of dimethoate up to concentration of $500 \mathrm{mg} / \mathrm{L}$. Li et al. (2010) reported that Paracoccus sp. Lgjj-3 is able to utilize the same concentration of dimethoate $(0.1 \mathrm{mg} / \mathrm{ml})$. Pseudomonas putida and Bacillus pumilus reported maximum dimethoate degradation at concentration of 0.09 and 0.06 $\mathrm{mg} / \mathrm{ml}$ of dimethoate, respectively (Jayamadhuri, 2014). In the present study, the growth in terms of optical density of $L$. sphaericus DM-3 was higher than the growth of B. cereus DM-5. Hence, the difference in degradation capability of various strains may be due to difference in enzyme system 
required for degradation and/or difference in their growth rate (Bhattacharjee et al., 2014).

Four mechanisms have been proposed for dimethoate degradation: $\mathrm{OH}$ attack on the $\mathrm{P}=\mathrm{S}$ bond, $\mathrm{OH}$ attack the $\mathrm{P}-\mathrm{S}$ bond, the hydrolytic cleavage of thioester bond and pyrolytic decomposition of dimethoate (Yao et al., 2011). Moreover, various enzymes are involved in the degradation of dimethoate such as esterase, aldoketo reductase, hydrolase and amidohydrolase (Liu et al 2001; Li et al. 2010 and Chen et al. 2016). The degradation of dimethoate can occur at the $\mathrm{P}-\mathrm{O}-\mathrm{C}, \mathrm{P}-\mathrm{S}$ or amide links of the molecule and then $\mathrm{P}=\mathrm{S}$ bond may be oxidized by $\mathrm{H}_{2} \mathrm{O}_{2}$ to form $\mathrm{P}=\mathrm{O}$ group (Wu et al. 2018).

In the current study, the main products of dimethoate biodegradation in aqueous fraction of culture filtrate of DM-3 and DM-5 were detected by GC/MS analysis. Among the various compounds detected, only one dimethoate degradation product, O,O,S-trimethyl phosphorothioate, was present in the degradation assay mixture for both strains. This result suggests that degradation of dimethoate by L. sphaericus DM-3 and B. cereus DM-5 is mainly preceded via enzymatic hydrolysis of $\mathrm{S}-\mathrm{CH}_{3}$ linkage. Supporting this explanation, Yao et al. (2011) proposed that $\mathrm{O}, \mathrm{O}, \mathrm{S}$-trimethyl phosphorothioate could be produced by the cleavage of $\mathrm{S}-\mathrm{CH}_{3}$ linkage of dimethoate. Thereafter, O,O-dimethyl phosphorothioate could be further degraded into $\mathrm{PO}^{4+}, \mathrm{CO}_{2}$ and $\mathrm{H}_{2} \mathrm{O}$ (Evgenidou et al. 2006).

\section{Conclusion}

the present study points out the efficiency of $L$. sphaericus DM-3 and B. cereus DM-5 to degrade dimethoate, up to $500 \mathrm{mg} / \mathrm{L}$, over a wide range of $\mathrm{pH}$ (4-12). Such degradation was not accompanied by production of the toxic byproducts, omethoate, whereas O,O-dimethyl phosphorothioate was the major biodegradation product. Moreover, enzymatic hydrolysis of $\mathrm{S}-\mathrm{CH}_{3}$ linkage is the probable mechanism for degradation of dimethoate by the two bacterial strains.

\section{References}

Al-Haifi, M.A., Khan, M.Z., Abdullah, V.M. and Ghole, S. (2006) Effect of dimethoate residues on soil micro-arthropods population in the valley of Zendan, Yemen Journal of Applied Sciences and Environmental Management, 10, $37-41$.
Baez-Rogelio, A., Morales-García, Y.E., QuinteroHernández, V. and Muñoz-Rojas, J. (2017) Next generation of microbial inoculants for agriculture and bioremediation. Microbial Biotechnology, 10, 19-21.

Begum, S.M., Rajesh, G. and Narendran, R.R. (2016) Isolation, characterization and identification of dimethoate degrading bacteria from soil series of tamil nadu. International Journal of Advanced Scientific and Technical Research, 3, 220-230.

Bhattacharjee, K., Banerjee, S., Bawitlung, L., Krishnappa, D. and Joshi, S.R. (2014) A study on parameters optimization for degradation of endosulfan by bacterial consortia isolated from contaminated soil. Proceedings of the National Academy of Sciences, India Section B: Biological Sciences, 84, 657-667.

Chanika, E., Georgiadou, D., Soueref, E., Karas, P., Karanasios, E., Tsiropoulos, N.G., Tzortzakakis, E.A. and Karpouzas, D.G. (2011) Isolation of soil bacteria able to hydrolyze both organophosphate and carbamate pesticides. Bioresource Technology, 102, 3184-3192.

Chen, Q., Chen, K., Ni, H., Zhuang, W., Wang, H., Zhu, J., He, Q. and He, J. ( 2016) A novel amidohydrolase (DmhA) from Sphingomonas sp. that can hydrolyze the organophosphorus pesticide dimethoate to dimethoate carboxylic acid and methylamine. Biotechnology Letters, 38, 703-710.

Coorevits, A., Dinsdale, A.E., Heyrman, J., Schumann, P., Van Landschoot, A., Logan, N.A. and De Vos, P., (2012) Lysinibacillus macroides sp. nov., nom. rev. International Journal of Systematic and Evolutionary Microbiology, 62, 1121-1127.

Darsa, K.V., Thatheyus, A.J. and Ramya, D. (2014) Biodegradation of petroleum compound using the bacterium Bacillus subtilis. Science International, 2, 20-25.

DebMandal, M., Mandal, S., Pal, N.K. and Aich, A. (2008) Potential metabolites of dimethoate produced by bacterial degradation. World Journal of Microbiology and Biotechnology, 24, 69-72.

Deshpande, N.M., Dhakephalkar, P.K. and Kanekar, P.P. (2001) Plasmid-mediated dimethoate degradation in Pseudomonas aeruginosa MCMB-427. Letters in Applied Microbiology, 33, 275-279.

Essa, A.M., Reyad, A.M., Radwan, T.E. and Ibrahim, W.M. (2016) Biodegradation of the organophosphorus insecticide diazinon by 
Pseudomonas aeruginosa isolated from agricultural drainage ditches. Egyptian Journal of Botany, 56, 353-370.

Evgenidou, E., Konstantinou, I., Fytianos, K. and Albanis, T. (2006) Study of the removal of dichlorvos and dimethoate in a titanium dioxide mediated photocatalytic process through the examination of intermediates and the reaction mechanism. Journal of Hazardous Materials, 137, 1056-1064

Francis, C.A. and Tebo, B.M. (2002). Enzymatic manganese (II) oxidation by metabolically dormant spores of diverse Bacillus species. Applied and Environmental Microbiology, 68, 874-880.

Geed, S.R., Kureel, M.K., Shukla, A.K., Singh, R.S. and Rai, B.N. (2016) Biodegradation of malathion and evaluation of kinetic parameters using three bacterial species. Resource-Efficient Technologies, 2, 3-11.

Jayamadhuri, R. (2014) Degradation of dimethoate by cellulolytic bacteria in cotton Soils. Global Journal of Medical Research, 14, 0-4.

Johnson, K.M. and Busta, F.F. (1984) Heat-induced temperature sensitivity of outgrowing Bacillus cereus spores. Applied and Environmental Microbiology, 47,768-774.

Khan, S., Zaffar, H., Irshad, U., Ahmad, R., Khan, A.R., Shah, M.M., Bilal, M., Iqbal, M. and Naqvi, T. (2016) Biodegradation of malathion by Bacillus licheniformis strain ML-1. Archives of Biological Sciences, 68, 51-59.

Kumar, P.C. and Gurupadayya, B.M. (2013) Analytical method development and validation of dimethoate pesticide using HPLC method. Biochemistry \& Analytical Biochemistry Journal, 2, 2161-1009.

Li, R., Zheng, J., Wang, R., Song, Y., Chen, Q., Yang, X., Li, S. and Jiang, J. (2010) Biochemical degradation pathway of dimethoate by Paracoccus sp. Lgjj-3 isolated from treatment wastewater. International Biodeterioration \& Biodegradation, 64, 51-57.

Liu, Y.H., Chung, Y.C. and Xiong, Y. (2001)Purification and characterization of a dimethoate-degrading enzyme of Aspergillus niger ZHY256, isolated from sewage. Applied and Environmental Microbiology, 67, 3746-3749.

Lovley, D.R. (2003) Cleaning up with genomics: Applying molecular biology to bioremediation. Nature Reviews Microbiology, 1, 35-44.
Manchola, L. and Dussán, J. (2014) Lysinibacillus sphaericus and Geobacillus sp biodegradation of petroleum hydrocarbons and biosurfactant production. Remediation Journal, 25, 85-100.

Mandal, M.D., Mandal, S. and Pal, N.K. (2005) Plasmid-mediated dimethoate degradation by Bacillus licheniformis isolated from a fresh water fish Labeo rohita. Journal of Biomedicine and Biotechnology, 2005, 280-286.

Ngoula, F., Watcho, P., Kenfack, A., Manga, J.N.Z., Defang, H.F., Pierre, K. and Joseph, T. (2014) Effect of dimethoate (an organophosphate insecticide) on the reproductive system and fertility of adult male rat. American Journal of Pharmacology and Toxicology, 9, 75.

Ortiz-Hernández, M.L., Sánchez-Salinas, E., DantánGonzález, E. and Castrejón-Godínez, M.L. (2013) Pesticide biodegradation: Mechanisms, genetics and strategies to enhance the process. In: "Biodegradation-life of Science". Intech, pp.251286.

Padan, E., Bibi, E., Ito, M. and Krulwich, T.A. (2005) Alkaline $\mathrm{pH}$ homeostasis in bacteria: New insights. Biochimica et Biophysica Acta (BBA)Biomembranes, 1717, 67-88

Qayoom, I., Shah, F.A., Mukhtar, M., Balkhi, M.H., Bhat, F.A. and Bhat, B.A.( 2016) Dimethoate induced behavioural changes in juveniles of Cyprinus carpio var. communis under temperate conditions of kashmir, India. The Scientific World Journal, 2016, 1-6.

Reuber, M. D. (1984). Carcinogenicity of dimethoate. Environmental Research, 34, 193-211.

Saleem, M., Ahmad, S. and Ahmad, M. (2014) Potential of Bacillus cereus for bioremediation of pulp and paper industrial waste. Annals of Microbiology, 64, 823-829.

Singh, B.K. and Walker, A. (2006) Microbial degradation of organophosphorus compounds. FEMS Microbiology Reviews, 30, 428-471.

Sneath, P.H., Mair, N.S., Sharpe, M.E. and Holt, J.G. (1986) "Bergey's Manual of Systematic Bacteriology". Volume 2. Williams \& Wilkins.

Sogorb, M.A. and Vilanova, E. (2002) Enzymes involved in the detoxification of organophosphorus, carbamate and pyrethroid insecticides through hydrolysis, Toxicology Letters, 128, 215-228.

U.S. Environmental Protection Agency, (2009) Final 
third drinking water contaminant candidate list (CCL3): Fact sheet. [Washington, D.C.], U.S. Environmental Protection Agency, Office of Water.

Van Scoy, A., Pennell, A. and Zhang, X. (2016) Environmental fate and toxicology of dimethoate. Reviews of Environmental Contamination and Toxicology, 237, 53-70.

Vermeire, T., McPhail, R. and Waters, M. (2001) D. organophosphorous pesticides in the environment. In: World Health Organization. IV. Meeting Report of the International Workshop on Approaches to Integrated Risk Assessment, pp.1-18.

Wan, S., Li, G., An, T., Guo, B., Sun, L., Zu, L. and Ren, A.( 2010) Biodegradation of ethanethiol in aqueous medium by a new Lysinibacillus sphaericus strain RG-1 isolated from activated sludge. Biodegradation, 21, 1057-1066.

Wang, Q.L., Zhang, Y.J., Zhou, C.X., Zhang, J., Dou, Y. and Li, Q.Q. (2013) Risk assessment of mouse gastric tissue cancer induced by dichlorvos and dimethoate. Oncology Letters, 5, 1385-1389.

Wu, L., Chládková, B., Lechtenfeld, O.J., Lian, S., Schindelka, J., Herrmann, H. and Richnow, H.H. (2018) Characterizing chemical transformation of organophosphorus compounds by ${ }^{13} \mathrm{C}$ and ${ }^{2} \mathrm{H}$ stable isotope analysis. Science of the Total Environment, 615, 20-28.

Yao, J.J., Hoffmann, M.R., Gao, N.Y., Zhang, Z. and Li, L. (2011) Sonolytic degradation of dimethoate: Kinetics, mechanisms and toxic intermediates controlling. Water Research, 45, 5886-5894.

Zhang, J., Yin, J.G., Hang, B.J., Cai, S., He, J., Zhou, S.G. and Li, S.P. (2012) Cloning of a novel arylamidase gene from Paracoccus sp. strain FLN7 that hydrolyzes amide pesticides. Applied and Environmental Microbiology, 78, 4848-4855.

(Received 14 / 2 /2018; accepted $25 / 2$ /2018)

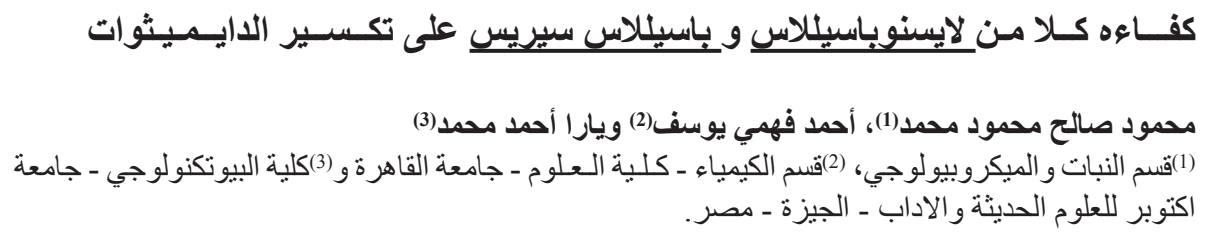

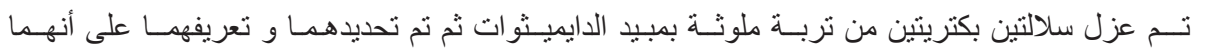

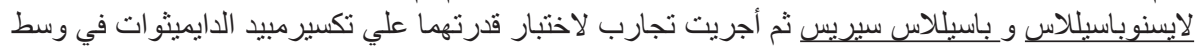

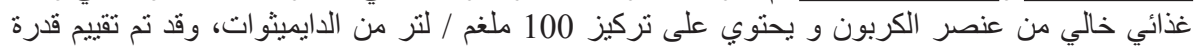

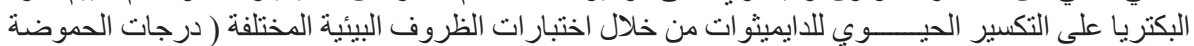

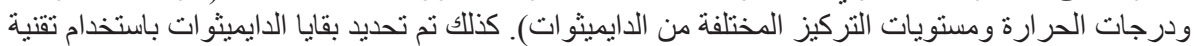

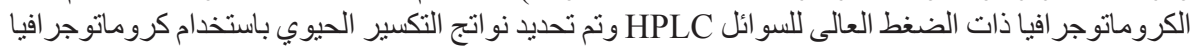

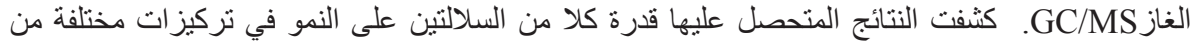

$$
\text { الدايميثو ات 500- 100ملغم / لتر. }
$$

وكانت درجة الحرارة الملائمة لنمو السلالتين هي 28 درجة مئوية و كان أعلى نمو لكلا من السلالتين

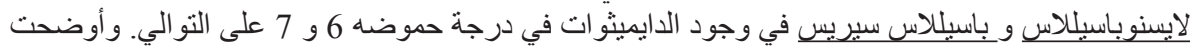

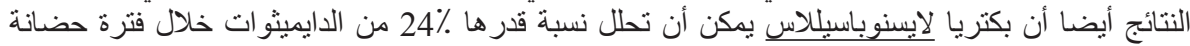

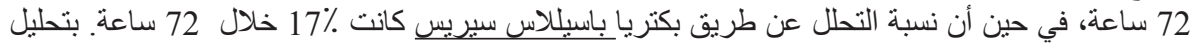

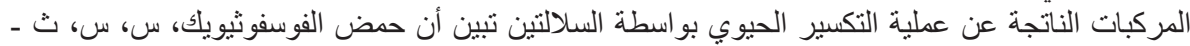

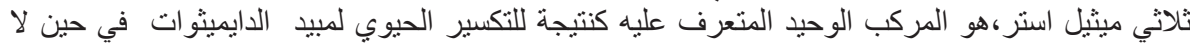

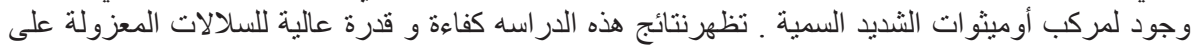

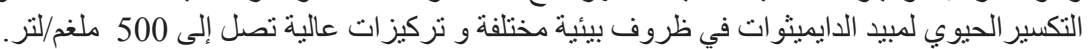

